\title{
Historical perspective on the place of international human rights treaties in the legal system of Lesotho: Moving beyond the monist-dualist dichotomy
}

\author{
Itumeleng Shale* \\ Lecturer, National University of Lesotho; Advocate of the courts of Lesotho \\ https://orcid.org/0000-0003-2284-3044
}

\begin{abstract}
Summary
This article reviews the relationship between international law and domestic law in the legal system of Lesotho. It explores the theories of monism and dualism and their usefulness in the protection of human rights in the legal system of Lesotho. It is argued that while Lesotho traditionally has been categorised as dualist, its conduct from before independence to date is not fully supportive of the tenets of this theory. This status is illustrated through a discussion of Lesotho's approach to international law during its territorial disputes with South Africa, and its attitude towards international instruments ratified both by the United Kingdom on behalf of Lesotho during the time it was a British Protectorate and after independence. The article also analyses the application and rejection of customary international law and international treaties by the courts of Lesotho. On the basis of this analysis it is concluded that the monist-dualist dichotomy no longer is useful in the protection of human rights as reflected in the courts' emphasis that Lesotho has to comply with its international human rights obligations. It is therefore recommended that the dichotomisation be discarded in favour of human rights protection regardless of whether the human rights norms are contained in international or in domestic law.
\end{abstract}

Key words: monism; dualism; human rights; domestication; Lesotho

LLB (NUL) LLM (Pretoria) PhD (Witwatersrand); itumelengshale@yahoo.com. This article is drawn from the author's PhD thesis titled 'Domestic implementation of international human rights standards against torture in Lesotho' (with further elaboration in the article). 


\section{Introduction}

Certainty of the place occupied by international law in any domestic legal system is important. This is more so with respect to the protection of human rights since most human rights standards are contained in instruments adopted at the global, regional and subregional levels, in this article collectively referred to as international instruments. Harmonisation of the two legal systems is a state obligation which is contained in the majority of international human rights instruments. ${ }^{1}$ This obligation has also been emphasised in the jurisprudence of international courts and tribunals, ${ }^{2}$ as well as in Concluding Observations. ${ }^{3}$ According to Oppong, the relationship between domestic and international legal systems determines 'the extent to which individuals can rely on internal law for the vindication of their rights within the national legal system'. ${ }^{4}$

As are many countries in the world, Lesotho is a party to several international human rights treaties that create general and specific obligations for state parties. While the massive adoption of international human rights instruments is highly commendable, in order for these instruments to benefit the individuals for whom they are intended, the norms contained therein must be made to matter nationally. ${ }^{5}$ Individuals must be able, at the national level, to enforce the rights contained in the ratified instruments. ${ }^{6}$ Viljoen summarises the process of aligning national legal systems with the international

1 Eg, art 2(2) of the International Convenant on Civil and Political Rights, art 2(1) of the International Convenant on Economic, Social and Cultural Rights, art 2(1) of the Convention Against Torture and art 1 of the African Charter on Human and Peoples' Rights mandate state parties to adopt legislative measures to give effect to their provisions.

2 Eg, in the case of Abdel Hadi \& Others $v$ Republic of Sudan Communication 368/ 2009, November 2013, 54th ordinary session, the African Commission on Human and Peoples' Rights held that the state's failure to put in place an adequate legislative framework to protect the integrity of individuals is a violation of art 1 of the African Charter. Similarly, in Mikhail Pustovoit v Ukraine Communication 1405/ 2005 (HRC), 12 May 2014 UN Doc CCPR/110/D/1405/2005(2014) para 11, the Human Rights Committee (HRC) held that in accordance with art 2(3)(a) of ICCPR the state party is under an obligation to ensure necessary modifications to its laws and practice so as to prevent acts that violate the Covenant.

3 Committee Against Torture, Concluding Observations on the combined 4th fourth and 5th periodic reports of Australia, 26 November 2014, UN Doc CAT/C/ SR.1284 and 1285 paras $5 \& 20$, where the Committee welcomed the adoption of national measures aimed at the implementation of the provisions of CAT as positive aspects of the report.

4 RF Oppong 'Re-imagining international law: An examination of recent trends in the reception of international law into national legal systems in Africa' (2006) 30 Fordham International Law Journal 3.

$5 \quad$ F Viljoen International human rights law in Africa (2011) 10.

6 See Preambles to the UN Charter, the Universal Declaration, ICCPR and ICESCR, all of which recognise that the effective protection of human rights at the national level is the foundation of justice and peace, and of social as well as economic development throughout the world. 
human rights standards as 'bringing human rights home' ${ }^{7}$ He argues that when states ratify the international human rights instruments, they undertake to implement the rights contained therein and thereby assume the responsibility to bring the rights home, to the national level. ${ }^{8}$ It is at the national level that individuals easily can access and enforce against their own governments the rights and obligations contained in the ratified international human rights treaties. 9 Hence, the principle of subsidiarity requires individuals to exhaust local remedies before approaching an international or regional body to vindicate their human rights. ${ }^{\text {to }}$

Lesotho traditionally has been categorised as dualist. ${ }^{11}$ It may be argued that Lesotho's dualist approach to international law is inferred from the constitutional supremacy clause in section 2 of its Constitution as well as the fact that other pieces of legislation expressly mention the international instruments which they seek to implement. ${ }^{12}$ However, it is illustrated in part 4 of the article that as far as human rights protection is concerned, there has been a paradigm shift in terms of which the courts - although it is not clear whether this was deliberate or not - have applied provisions of international instruments directly without probing into their domestication or otherwise. Because of the lack of a clear constitutional provision on how the courts must treat such instruments, there are also cases in which the courts have totally disregarded international instruments and pronounced that these cannot overrule either Sesotho customary law or statutes if they have not been domesticated into national laws. This inconsistency demonstrates that there is a need to change the stance as the categorisation no longer is helpful.

7 Viljoen (n 5) 10.

8 As above.

9 As above.

10 Art 56(7) of the African Charter requires the exhaustion of local remedies. See Socio-Economic Rights and Accountability Project (SERAP) v Nigeria (2010) AHRLR 102 (ACHPR 2010); see also Muzerengwa \& Others v Zimbabwe (2011) AHRLR 160 (ACHPR 2011); see also art 22(4)(b) of CAT which requires the exhaustion of local remedies; $H V$ Sweden Communication 627/2014 (Committee against Torture), 5 August 2016, UN Doc CAT/C/58/D/627/2014 para 7.5; EE $v$ The Russian Federation Communication 479/2011 (Committee against Torture), 26 August 2012, UN Doc CAT/C/50/D/479/2011 para 8.4; and BR v Italy Communication 598/2014 (Committee against Torture) 12 June 2016, UN Doc CAT/C/57/D/598/ 2014 para 6 which were dismissed for failure to exhaust local remedies.

11 TK Saha \& L Abdulrauf 'Introductory note on the 1993 Constitution of Lesotho' 25, www.icla.up.ac.za/images/country_reports/lesotho_country_report.pdf (accessed 20 March 2019).

12 Eg, part IV of the Penal Code Act 2010 which deals with international crimes specifically states that the terms used in that section, such as torture, enslavement and others, bear the same meaning as that used in international law. The Children's Protection and Welfare Act provides that it applies the principle of best interests of the child as expounded in the Convention on the Rights of the Child (CRC) and African Charter on the Rights and Welfare of the Child. 
From a historical perspective the article unpacks the place which international law occupied and continues to occupy in the legal system of Lesotho. The perceptions of states and scholars in this regard are divergent and are expressed from two main theories of incorporation: monism and dualism. These theories often are employed to determine the hierarchy of the two legal systems and to assist courts of law in determining which one will prevail when the two clash. ${ }^{13}$ In this article it is argued that from a historical perspective the practical approach to international law in Lesotho does not fit into either of the two theories, which illustrates that an attempt to categorise Lesotho as either monist or dualist is not helpful.

The article is structured into five parts: an introduction; a brief overview of the theories of monism and dualism; a historical perspective on the place of international law in the legal system of Lesotho from the time of independence to date; the judicial application of both international treaties and international customary law; and, lastly, a conclusion that the practice as illustrated in parts 3 and 4 fails to fit into the theories of monism and dualism as discussed in part 2, regardless of whether the instruments presented before court have been adopted at the continental, regional or sub-regional level.

\section{Theories of incorporation}

\subsection{Monism}

The origin of this theory is traced to the natural law school of thought. Its proponents view international law and municipal law as a single unity composed of binding legal rules. ${ }^{14}$ They posit that there is a single universal system of law and that international law and municipal law are aspects of such a system. Monists insist that the two legal systems are interrelated parts of one legal structure. ${ }^{15}$ Further arguments advanced by the natural law scholars are that whereas international instruments are concluded between and among states, the real subjects of the norms contained therein are individual human beings, ${ }^{16}$ and states are given responsibilities to protect those rights for the benefit of individuals.

According to the theory of monism, when confronted with a case, municipal courts are obliged to directly apply rules of international

13 XF Torrijo 'International law and domestic law: Definitely an odd couple' (2008) 77 Revista Juńdica Universidad de Puerto Rico 485.

14 JG Starke 'Monism and dualism in the theory of international law' in SL Paulson (ed) Normativity and norms: Critical perspectives on Kelsenian themes (1999), www.oxfordscholarship.com (accessed 16 August 2017).

15 As above.

16 A Clapham 'The role of the individual in international law' (2010) 21 European Journal of International Law 25. 
law in the same manner as municipal laws. ${ }^{17}$ Where the two legal systems clash, monism gives preference to rules of international law. ${ }^{18}$ In its purest form monism dictates that international law prevails over national laws and that a national law that contradicts an international instrument is null and void, even if that national law is a constitution, whether passed prior to or after the state's ratification of or accession to the international instrument in question. ${ }^{19}$ The supremacy of international law over municipal law in both international and national decisions thus underlies the theory of monism.

\subsection{Dualism}

Dualism is the direct opposite of monism. Unlike monism, in terms of which international law and national law are viewed as part of one legal system, dualism treats international law and municipal law as two entirely distinct and separate legal systems. ${ }^{20}$ Unlike in the case of monism, where the underlying principle is that international law must prevail over domestic law in both international and national decisions, ${ }^{21}$ the dualist theory asserts that international law should be limited to international decisions and should not prevail over domestic law in domestic decisions. ${ }^{22}$ International law, however, may be resorted to as a guide to interpret domestic law where such a need arises. In relation to dualism Dugard states that domestic courts can apply international law only if (a) it has been adopted by the state; or (b) it has been transformed into domestic law by national legislation. ${ }^{23}$ In dualist jurisdictions, international law is regarded as having been incorporated into the domestic legal order only when expressly stated by a legislative enactment or when its articles are included, although not expressly, into domestic law. ${ }^{24}$ In these jurisdictions national courts are restricted to the application of domestic laws. Therefore, in order for a rule of international law to be applied, it must first be transformed into national law through legislation, failing which the courts cannot apply it. ${ }^{25}$ Hence, dualism is also known as the transformation or adoption theory. ${ }^{26}$ In most

17 DP O'Connell 'The relationship between international law and municipal law' (1960) 4 Georgetown Law Journal 432.

18 JF Coyle 'Incorporative statutes and the borrowed treaty rule' (2010) 50 Virginia Journal of International law 656.

19 M Killander \& $H$ Adjolohoun 'International law and domestic human rights litigation in Africa: An introduction' in M Killander (ed) International law and domestic human rights litigation in Africa (2010) 5.

20 O'Connell (n 17) 432.

21 As above.

22 As above.

23 J Dugard International law: A South African perspective (2011) 46.

24 Killander \& Adjolohoun (n 19) 9. See also Basotho National Party \& Another $v$ Government of Lesotho \& Others Constitutional Case 5/2000 [2003] LSHC 622.

25 Killander \& Adjolohoun (n 19) 9.

26 As above. 
dualist states this transformation is regulated by domestic constitutional law.

Dualism derives from the positive law school of thought which asserts that international law and national law are totally different systems in that they originate from different sources and regulate different subject matters. ${ }^{27}$ Positivists assert that states, rather than individuals, are the primary subjects of international law and, therefore, that the application of international law should be limited to the regulation of relationships and the resolution of disputes between states and not between individuals and the state or between individuals at the national level where individuals are subjects of the law. 28

Dualism was traditionally justified - and some conservative scholars and judicial officers still adhere to this justification - by arguments based on principles of state sovereignty and the separation of powers. This position is reflected in the old decisions of most jurisdictions with a common law background such as Lesotho. For instance, in the case of Gondwe $e^{29}$ Nyirenda J of the Malawian High Court said the following in relation to state sovereignty and the application of international law by national courts: ${ }^{30}$

The doctrine of state sovereignty and supremacy of Parliament in legislating [is] the basis, I believe, upon which, in common law jurisdictions, international law must be incorporated in municipal law for it to be enforceable. It logically follows therefore that the sovereign states have the authority to determine the extent and limit to which they wish to incorporate international law.

Similar sentiments regarding separation of powers were echoed by Steyn CJ in the South African case of Pan-American World Airways Incorporated v SA Fire and Accident Insurance, in which he said: ${ }^{31}$

In this country, the conclusion of a treaty, convention or agreement by the South African government with any other government is an executive and not a legislative act. As a general rule, the provisions of an international instrument so concluded, are not embodied in our law except by a legislative process ... In the absence of any enactment giving its relevant provisions the force of law, it cannot affect the rights of the subject.

27 Starke (n 14). See also G Erasmus 'The Namibian Constitution and the application of international law' (1989/90) 15 South African Yearbook of International Law 84.

28 Erasmus (n 27).

29 Gondwe v Attorney-General [1996] MLR 492 (HC).

30 In Malawi the parliamentary supremacy argument, however, was superseded by the constitutional supremacy clause inserted in the 1994 Constitution which also incorporates the application of international law in the interpretation of the Constitution and in relation to the limitation of and derogation from the rights contained in the Constitution. See RE Kapindu 'The relevance of international law in judicial decision-making in Malawi' in Southern African Litigation Centre et al (eds) Using the courts to protect vulnerable people (2015) 77.

31 Pan-American World Airways Incorporated v SA Fire and Accident Insurance 1965 (3) SA 150 at 161. With the advent of the 1996 Constitution, the South African position with regard to the relationship between international and national laws has since changed. These changes are discussed later in this part. 
The challenge that the courts addressed in these decisions is that in many jurisdictions, that of Lesotho included, the legislature plays no role in the negotiation and ratification of an international treaty. Therefore, the direct application of international instruments would be contradictory to the principle of separation of powers in that the executive would have enacted the law by signing an international instrument, which the court is then called upon to interpret, thus bypassing the legislature in the entire process.

Having outlined the main features of each of these theories, the next part analyses from a historical perspective how international law has interfaced in the legal system of Lesotho from the time of the founding of the Basotho nation to date.

\section{Relationship between international law and domestic law in Lesotho}

Although research has been conducted on the domestic implementation of international law in other jurisdictions and factors that enable or inhibit such implementation, looking at current literature on the subject, little is known about the place of international law in the legal system of Lesotho except for an emphasis on the fact that Lesotho is a dualist country. This, it is assumed, is based on Lesotho's history which includes the heritage of the Roman-Dutch common law as well as the constitutional supremacy clause in section 2 of the Constitution. ${ }^{32}$

The next parts demonstrate that as far as the protection of human rights is concerned, Lesotho's conduct, including the ratification of international instruments, the enactment of corresponding domestic laws, the submission of reports to relevant treaty bodies, and the courts' reasoning for accepting or rejecting the application of international instruments neither supports its categorisation as dualist nor suggests that Lesotho is monist, thus leading to a conclusion that this categorisation no longer is helpful.

\subsection{Position of international law in the legal system of Lesotho prior to independence}

Lesotho was formerly known as Basutoland, named after a nation called the Basotho which occupied the territory during the $1800 \mathrm{~s}^{33}$ The Basotho nation was founded by Moshoeshoe who unified people from a number of clans who had come to him for protection having fled their homelands in the 1800s due to the invasion by Shaka Zulu

32 G) van Niekerk 'Constitutional protection of common law: The endurance of civilian tradition in Southern Africa' (2012) 18 Fundamina: A Journal of Legal History 115.

33 S Rosenberg \& RF Weisfelder The historical dictionary of Lesotho (2013) 472. 
and the boers. ${ }^{34}$ These conflicts drove most indigenous Southern African communities out of their homelands and forced them to seek refuge in Thaba-Bosiu where Moshoeshoe had established a fortress. ${ }^{35}$ Moshoeshoe subsequently gathered all those who had come to him for protection and founded the Basotho nation of whom he became King. ${ }^{36}$ His Kingdom became known as Basutoland (later named Lesotho). ${ }^{37}$

During the Great Trek, the boers left the Cape Colony. ${ }^{38}$ In the mid-1820s they crossed the Orange River into Moshoeshoe's territory and allegedly requested from him a right to settle there. ${ }^{39}$ Moshoeshoe was of the opinion that he had lent the said territory to the boers but later they claimed to have rights over it. ${ }^{40}$ These divergent views about the ownership of land led to conflicts between the Basotho who occupied Basutoland and the boers who occupied territory in the current South Africa. ${ }^{41}$ The conflicts gave rise to a number of bilateral treaties between the two territories, thus bringing international law into play.

The first territorial treaty was signed between Moshoeshoe and Napier who represented Great Britain in $1843 .{ }^{42}$ According to this treaty the British recognised Basotho sovereignty over the land between the Orange and Caledon rivers. ${ }^{43}$ The boers, who had settled in some areas included in the 1843 treaty, did not recognise this description and continued their invasion and attempts to conquer more of Moshoeshoe's land. ${ }^{44}$ In 1845 the territorial treaty was altered by Governor Maitland to legally recognise the boer settlement. ${ }^{45}$ The alteration of the 1843 treaty fuelled more conflict between the Basotho and the boers. The British ended up drawing new boundaries which separated the territories, this time leaving less land for Moshoeshoe. These boundaries became known as the Warden Line (named after the British Resident in Bloemfontein, Henry Warden). ${ }^{46}$ The Warden Line was not welcomed by Moshoeshoe and his people and a fierce conflict between the British and the Basotho

34 The white settlers were also known as the boers. S Poulter Legal dualism in Lesotho (1981) 1.

35 As above.

36 As above.

37 As above.

38 South African History Online 'Basotho wars: 1858-1868', http://www.sahistory. org.za/south-africa-1806-1899/basotho-wars-1858-1868 (accessed 14 October 2017).

39 As above.

40 As above.

41 As above.

42 Napier Treaty of 1843.

43 EA Eldredge $A$ South African kingdom: The pursuit of security in nineteenth century Lesotho (1993) 50.

44 As above.

45 South African History Online (n 38).

46 Eldredge (n 43) 51. 
ensued, resulting in the Battle of Viervoet in 1851 and another in 1852 in the Berea Plateau. ${ }^{47}$ The British were defeated in both battles. They then realised that the cost of maintaining sovereignty was too high and they signed the Sand River Convention in terms of which they handed over the disputed territory to the boers. ${ }^{48}$

Upon their takeover, the boers demanded land beyond the Caledon River, and named the new territory the Republic of the Orange Free State (Free State). ${ }^{49}$ The demand for more land ignited new feuds between the Basotho and the boers. The President of the Free State, Jacobus Nicolaas Boshoff, declared war against the Basotho, resulting in the War of Senegal in March 1858 in which Moshoeshoe was almost defeated. ${ }^{50}$ After this war, an uneasy peace between the two territories followed, and in 1861 Moshoeshoe requested protection from Britain. ${ }^{51}$ Moshoeshoe's request for Britain's involvement in the conflict between himself and the boers also brought international law into the picture.

In 1865 the Free State launched heavy attacks against Moshoeshoe and his people. This conflict became known as the Seqiti War. ${ }^{52}$ By the late 1860s, Moshoeshoe and the Basotho people were exhausted and on the edge of famine as a result of these struggles. ${ }^{53}$ Their total defeat by the boers loomed. ${ }^{54}$ Moshoeshoe then renewed his entreaty for British protection and in March 1868 the Basotho Kingdom was declared a British protectorate. ${ }^{55}$ The boers discontinued the war and in February 1869, boundaries were agreed upon between Basutoland and the Republic of the Free State, now known as Lesotho and a province of South Africa respectively. These boundaries were drawn in the Convention of Aliwal North. ${ }^{56}$

The above history reflects that from its foundation as a sovereign Kingdom and even when it had become a British protectorate, Lesotho's relationship with its neighbour, South Africa, was governed by international law. The conflicts which Lesotho had with the British, as well as with the boers, resulted in the conclusion of several peace and boundary treaties. Moshoeshoe viewed the said international law as binding on him and his people. To date, the boundaries between Lesotho and South Africa remain as stipulated in the Aliwal North Convention. However, there is no literature suggesting that international law was applied to solve domestic disputes during Moshoeshoe's reign. This situation could be influenced by several

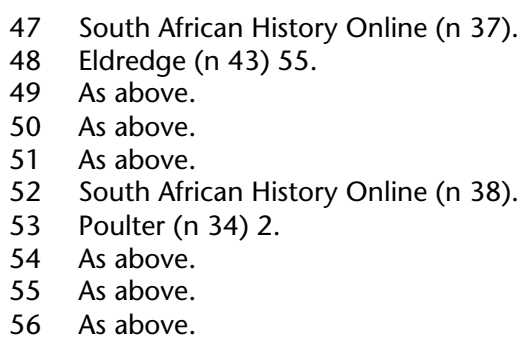


factors, such as the fact that during that time Moshoeshoe and his chiefs, who also acted as legislatures, focused more on stabilising their territories and solving territorial disputes than on internal disputes among their subjects. ${ }^{37}$ Another factor could be the effect of General Proclamation 2B of 1884 which dictated that domestic disputes were to be resolved by domestic laws.

The British handed the administration of Basutoland to the Cape legislature since it realised that due to non-ending conflicts, its administration would be expensive and not easy to handle. ${ }^{58}$ As far as the legal system was concerned, the High Commissioner issued General Law Proclamation 2B of 1884 (Proclamation) which made law that was applicable in the Colony of the Cape of Good Hope at the time to be equally applicable in Lesotho. The Proclamation reads as follows: 59

In all suits, actions or proceedings, civil or criminal, the law to be administered shall, as nearly as the circumstances of the country will permit, be the same as the law for the time being in force in the Colony of the Cape of Good Hope: Provided, however, that in any suits, actions, or proceedings in any court, to which all parties are Africans, and in all suits, outcomes or proceedings whatsoever before any Basotho courts, African law may be administered.

This Proclamation imported Roman-Dutch law and its legal traditions into Lesotho although it still left room for the application of African law (later known as Sesotho customary law). It created a dualist system which still applies today, in which Sesotho customary law operates side by side with the 'received law'.60 Presumably, it is at this stage that the Roman-Dutch law traditions, including a dualist approach to international law, were imported into the legal system of Lesotho.

During the time when Lesotho was its protectorate, the United Kingdom concluded international treaties and extended their application to Lesotho. At the same time the Cape passed proclamations which were meant to run the country. Proclamation $2 \mathrm{~B}$ made no reference to international law nor to its status vis-à-vis other proclamations that were passed. However, an inference that can be drawn from its wording is that the status of international conventions in Lesotho during its protectorate days would be what obtained in the Cape Colony of Good Hope, which was dualism as influenced by the English legal system.

Although it is argued in this article that the categorisation of Lesotho as dualist is mainly influenced by the British legal system,

\footnotetext{
57 WCM Maqutu Contemporary constitutional history of Lesotho (1990) 17.

58 As above.

59 JE Beardsley 'The common law in Lesotho' (1970) 14 Journal of African Law 198.

60 T Thabane \& I Shale 'The impact of the African Charter and Women's Protocol in Lesotho' in Centre for Human Rights The impact of the African Charter and Women's Protocol in selected African states (2012) 79.
} 
Killander and Adjolohoun warn that 'the description of the English legal system as the epitome of dualism is arguably exaggerated' for a number of reasons. First, customary international law formed and continues to form part of the law of the land in England as well as in many common law countries; second, 'unincorporated treaties still play an increasingly important role, though the courts may not directly apply them' ${ }^{61}$ This objection notwithstanding, it suffices to conclude that the dualist approach to international law in Lesotho became more evident when Lesotho became a British protectorate. Therefore, the English legal system as introduced by Proclamation 2B acts as a cradle for continued dualism in Lesotho.

\subsection{Position of international law in the legal system of Lesotho post-independence to the state of emergency (1966-1970)}

Lesotho continued to be a British Protectorate until 1966 when it had its first democratic elections.

These elections were governed by the first Constitution, which came pursuant to a British Royal Decree in January $1965 .^{62}$ The elections prepared Lesotho for independence from Britain, and on 4 October 1966 it gained independence. Following the 1965 elections and the attainment of independence the 1966 Constitution was adopted on the basis of the Independence Order of 1966 passed by the Parliament of Lesotho. ${ }^{63}$ It largely followed the British model except that it had a Bill of Rights, which was similar to the United States constitutional practice. ${ }^{64}$

The 1966 Constitution did not make any provision for international law, but had a constitutional supremacy clause. ${ }^{65}$ That is, the international instruments to which Lesotho was a party would be applicable only to the extent that they did not contradict provisions of the Constitution.

As far as other laws which had been passed by the Colony of the Cape of Good Hope were concerned, the 1966 Constitution did not do away with these. They continued to operate. Some laws were slowly phased out and today some still form part of the laws of Lesotho. This status is highlighted by Palmer and Poulter as follows: ${ }^{66}$

The newly independent state of Lesotho took over the existing laws that had previously been in force in Basutoland, though in future they were to

61 Killander \& Adjolohoun (n 19) 11.

62 M Khaketla Lesotho 1970: An African coup under the microscope (1992) vii.

63 Maqutu (n 57) 17.

64 As above.

65 Sec 2 of the Constitution of Lesotho 1966 provided that '[t]he Constitution of Lesotho is the supreme law of Lesotho and if any other law is inconsistent with this Constitution, that other law shall, to the extent of the inconsistency, be void'.

66 V Palmer \& S Poulter The legal system of Lesotho (1972) 41; see also TLC Lenka 'A historical and comparative study of human rights violations in criminal investigations in Lesotho' unpublished LLD thesis, University of the Free State, 2010. 
be construed with any modifications, adaptations, qualifications and exceptions required to bring them into conformity with the independence legislation, namely the Constitution.

As an acknowledgment of the relevance of international law to Lesotho as a new independent state, in the same month that it gained independence Lesotho ratified three conventions of the International Labour Organisation (ILO). ${ }^{67}$ These conventions were later domesticated through the Labour Code Order 1992, which provides: 68

No provision of the Code or of rules and regulations made thereunder shall be interpreted or applied in such a way as to derogate from the provisions of any International Labour Convention which has entered into force for the Kingdom of Lesotho.

Lesotho also took cognisance of the fact that there were international treaties which the government of the United Kingdom had concluded on its behalf during the time when Lesotho was under British protection. However, Lesotho neither hastened to be bound immediately by these treaties, nor to discharge itself from their obligations altogether. It proposed a 24-month period, running from the date of independence, within which to review its position as regards these treaties. What was to happen to Lesotho's treaty obligations in the interim during this review period was contained in a letter of 22 March 1967 written by the Prime Minister of Lesotho to the Secretary-General of the United Nations (UN). The letter, which is quoted verbatim in the judgment, reads as follows: ${ }^{69}$

\section{Your Excellency}

The government of the Kingdom of Lesotho is mindful of the desirability of maintenance, to the fullest extent compatible with the emergence into full independence of the Kingdom of Lesotho, [of] legal continuity between Lesotho and the several states with which, through the actions of the government of the United Kingdom, the country formerly known as Basutoland enjoyed treaty relations. Accordingly, the government of the Kingdom of Lesotho takes the present opportunity of making the following declarations:

1 As regards bilateral treaties validly concluded by the government of the United Kingdom, on behalf of the country formerly known as Basutoland, or validly applied or extended by the said country to the country formerly known as Basutoland, the government of the Kingdom of Lesotho is willing to continue to apply within its territory on the basis of reciprocity, the terms of all such treaties for a period of twenty-four months from the date of independence (ie until October 4,1968 ) unless abrogated by mutual consent. At the expiry of that period, the government of the Kingdom of Lesotho will regard such

67 The Convention Concerning Forced or Compulsory Labour 1930; Right to Organise and Collective Bargaining Convention 1949; and Freedom of Association and the Right to Organise Convention 1948; all of which were ratified on 31 October 1966.

68 Sec 4(b) Labour Code Order 1992.

69 Joe Molefi v Legal Advisor \& Others [1970] 3 ALL ER 724, 17 June 1970 para 12, www.historicalpapers.wits.ac.za/inventories/inv_pdfo/AD1901-52-2-01jpeg.pdf (accessed 4 April 2017). 
of these treaties which could not by application of customary international law be regarded as otherwise surviving, as having terminated.

$\ldots$

3 The government of the Kingdom of Lesotho is conscious that the above declaration applicable to bilateral treaties cannot with equal facility be applied to multilateral treaties. As regards these, therefore, the government of the Kingdom of Lesotho proposes to review each of them individually and to indicate to the depository in each case what steps it wishes to take in relation to each such instrument, whether by way of confirmation of termination or confirmation of succession or accession. During such interim period of review, any state party to a multilateral treaty which has, prior to independence been applied or extended to the country formally known as Basutoland, may, on the basis of reciprocity, rely as against Lesotho on the term of such treaty.

It would be appreciated if your Excellency would arrange for the text of this declaration to be circulated amongst all members of the United Nations.

Please accept, Sir, the assurance of my highest consideration.

Signed LEABUA JONATHAN (Prime Minister)

The implications of this letter for Lesotho's international human rights obligations are discussed in more detail in the decision of the Privy Council, which at the time acted as Lesotho's Appeal Court, in the case of Joe Molefi $v$ Legal Advisors \& Others. ${ }^{70}$ What is important to highlight from this letter is that from the time of independence, Lesotho was aware that being a party to international treaties, whether bilateral or multilateral, carries with it certain obligations with which state parties are expected to comply. Hence, immediately upon entry into power the government took a stance as regards such obligations. The letter does not reflect a dualist approach to international law in which case the government would claim that in the absence of any domesticating laws any international instrument to which the British government was a party or made Basutoland a party would not be binding on the government of Lesotho.

After the 24-month review period Lesotho continued to ratify international treaties, such as the four Geneva Conventions 1949, 71 and the Convention of the Privileges and Immunities of the UN 1946. ${ }^{72}$ Some aspects of the Geneva Conventions have been domesticated in the Penal Code Act which criminalises grave breaches of international humanitarian law, including torture, committed as

\footnotetext{
70 As above.

71 Geneva Convention for the Amelioration of the Conditions of the Wounded and Sick in Armed Forces in the Field (1st Geneva Convention) 12 August 1949; Geneva Convention for the Amelioration of the Conditions of the Wounded and Sick and Shipwrecked Members of Armed Forces at Sea (2nd Geneva Convention); Geneva Convention Relative to the Treatment of Prisoners of War (3rd Geneva Convention); Geneva Convention Relative to the Protection of Civilian Persons in Time of War (4th Geneva Convention) 12 August 1949. Lesotho ratified all four Geneva Conventions on 20 May 1968.

72 Convention of the Privileges and Immunities of the UN 1946. Lesotho ratified this Convention on 26 November 1969.
} 
part of war crimes and crimes against humanity. ${ }^{73}$ The Penal Code Act specifically makes reference to the Geneva Conventions. ${ }^{74}$

\subsection{Position of international law in the legal system of Lesotho during the state of emergency (1970-1986)}

The 1966 Constitution was suspended in 1970 following Lesotho's second democratic elections. The then ruling party, the Basotho National Party (BNP), which had won the elections in 1965, lost to the opposition Basotho Congress Party (BCP). While the national radio station was announcing the results, the Prime Minister, Leabua Jonathan, made a public statement that Lesotho was in a state of emergency which warranted the suspension of the Constitution 'pending the drafting of a new one'. ${ }^{75}$ He said that the declaration of the state of emergency and suspension of the Constitution were necessitated by the fact that the elections were not fair as BNP supporters had been subjected to acts of violence. ${ }^{76}$ However, his statement did not allude to any flaws in the Constitution which called for its suspension or re-drafting. ${ }^{77}$

After suspending the Constitution, the Prime Minister then established a Council of Ministers (Council) composed of members of the former cabinet. The Council performed legislative functions, and in 1973 it passed the Lesotho Order of 1973, which established an Interim National Assembly (INA). The INA passed several laws from 1973 to 1986 when the military toppled the government through a coup d'état. Among laws passed by the INA was the Parliament Act of 1983 , which would act in the place of a Constitution. ${ }^{78}$ According to a number of authors who wrote on Lesotho's constitutional changes, the suspension of the Constitution was followed by massive human rights violations and a disregard for international law. ${ }^{79}$ It is argued that some of the human rights violations were sanctioned by laws passed by the Council of Ministers and the INA. ${ }^{80}$ Lesotho adopted an approach in terms of which the Prime Minister ignored all voices from the international community and stood firm that whatever was happening in Lesotho was Lesotho's problem, to be solved according to the laws of Lesotho, and that international law had no place in the national legal system. ${ }^{81}$

A dualist approach to international law in Lesotho during this period also can be inferred from the fact that there were laws

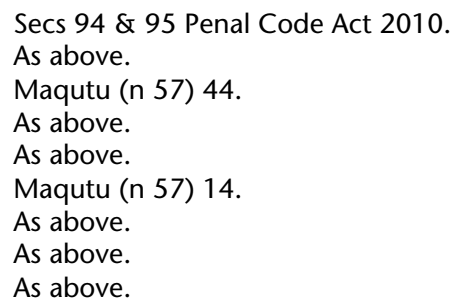


promulgated during the period which expressly stipulated that their enactment was meant to give effect to certain principles contained in international human rights instruments to which Lesotho is a party. For example, section 13 of the 1983 Refugee Act of Lesotho made specific reference to the UN Refugee Convention of 1951. The impression given by the express mention of a specific international instrument is that any other convention which is not expressly mentioned in an Act of Parliament is not considered law in Lesotho.

The BNP government continued its international relations and ratified a number of international treaties, including the Convention on the Elimination of All Forms of Racial Discrimination (CERD) in 1971; the Genocide Convention in 1974; as well as the UN Refugee Convention and its 1967 Protocol in 1981. ${ }^{82}$ However, during this period no domestic laws were enacted to implement the provisions of CERD and the Genocide Convention despite the fact that article 2(1) of CERD and article 5 of the Genocide Convention mandate state parties to adopt legislative measures to implement their provisions. As illustrated in the next part the only convention that was applied in the courts of law during this period was the Refugee Convention.

\subsection{Position of international law in the legal system of Lesotho during military rule (1986-1993)}

In 1986 the Royal Lesotho Defence Force (RLDF), under the leadership of Major General Metsing Lekhanya, launched a coup d'état against the BNP government. ${ }^{83}$ The military regime repealed the 1983 Act and passed Lesotho Order 2 of 1986, which was to operate as the country's Constitution. ${ }^{84}$ The military government ruled for approximately five years and in 1991 it was toppled by another group of the army called the 'captains' under the leadership of Colonel Elias Phitšoane Ramaema. ${ }^{85}$ The Ramaema military regime set aside the 1986 Order and promulgated Lesotho Order 2 of 1990 as the basis of its power. ${ }^{86}$

Unlike the 1966 Constitution which expressly provided for constitutional supremacy, the 1986 and 1991 Orders did not. Therefore, the place of international law vis-à-vis the laws of Lesotho during this time cannot be inferred from them. However, the military regime continued to ratify as well as accede to a number of

82 Conventions ratified during this period include CERD 1965; Supplementary Convention on Abolition of Slavery, Slave Trade and Institutions and Practices Similar to Slavery 1956; Convention on Status of Stateless Persons 1954; Genocide Convention 1948; International Convention for Suppression of Unlawful Seizure of Aircraft 1970; Convention against Taking of Hostages 1979; and UN Refugee Convention 1951.

83 Maqutu (n 57) 71.

84 Maqutu (n 57) 4.

85 JA Kalley, E Schoeman \& LE Andor Southern African political history: A chronology of key political events from independence to mid-1997 (1999) 149.

As above. 
international human rights instruments, including the Convention Governing Specific Aspects of Refugee Problems in Africa $1969{ }^{87}$ the International Covenant on Economic, Social and Cultural Rights 1966 (ICESCR); the International Covenant on Civil and Political Rights 1966 (ICCPR); the African Charter on Human and Peoples' Rights 1981 (African Charter); and the Convention on the Rights of the Child 1989 (CRC). It is interesting to note that despite this massive programme of ratification, no state party reports, as required by the treaty bodies overseeing the implementation of these instruments, were submitted by Lesotho during this period. Similarly, reports in respect of treaties that had earlier been ratified or acceded to by the BNP government also were not submitted. The conclusion that the status of international law in the legal system of Lesotho during this period remained unknown is supported by the fact that there is no case law to show the use of international law in Lesotho's domestic courts during this period.

\subsection{Position of international law in the legal system of Lesotho during democratic rule (1993 to present)}

In 1991, when Ramaema and 'the captains' removed Lekhanya from power, they promised to restore civilian rule. Indeed, in the following year, 1992, preparations for elections and the adoption of a new Constitution were made. Having been under a military regime for almost a decade, Lesotho held democratic elections, which ushered in a new Constitution in 1993. In the quest to align the legal system of Lesotho with international human rights standards, several oppressive laws passed by the self-imposed BNP government and the military regime also were repealed. The 1993 Constitution is in all material terms similar to the 1966 Constitution. It could be argued that the reason for this replication is that there were no concrete reasons which warranted suspension of the 1966 Constitution in the first place. Hence, Parliament found the contents of the 1966 Constitution equally applicable in Lesotho after the 1993 democratic elections. Unlike the constitutions of some other countries, such as the 1996 Constitution of South Africa, the 1993 Constitution of Lesotho is silent on both the status of international treaties and whether these can serve as judicial cause of action in Lesotho. ${ }^{88}$ However, just as does the 1966 Constitution, it has the supremacy clause which places all other laws subject to the Constitution. ${ }^{89}$

Since democratic rule in 1993 Lesotho ratified or acceded to several international human rights instruments, such as the Convention on the Elimination of All Forms of Discrimination Against Women (CEDAW); the Equal Remuneration Convention $1951{ }^{90}$ the

87 Lesotho ratified the Convention on 18 November 1988.

88 Secs 231 \& 232 Constitution of South Africa 1996.

89 Sec 2 Constitution of Lesotho 1993.

90 Lesotho ratified this Convention on 27 January 1998. 
Discrimination (Employment and Occupation) Convention 1958; ${ }^{91}$ the African Charter on the Rights and Welfare of the Child (African Children's Charter); the Optional Protocol to ICCPR 1966; ${ }^{92}$ the ILO Convention against Child Labour $1999 ;^{93}$ the Abolition of Forced Labour Convention $1957 ;^{94}$ the Convention against Torture and Other Cruel, Inhuman or Degrading Treatment or Punishment (CAT); the Occupational Health and Safety Convention 1981,95 the UN Convention Against Transnational Organised Crimes 2000; 96 the Protocol Against Smuggling of Migrants 2000; ${ }^{97}$ the Optional Protocol to CRC on the Involvement of Children in Armed Conflict $2000 ;{ }^{98}$ the Protocol to the African Charter on Establishment of the African Court on Human and Peoples' Rights $1998 ;{ }^{99}$ the Convention for the Suppression of Traffic in Persons $1949 ;{ }^{100}$ the Optional Protocol to CEDAW 1999; ${ }^{101}$ the Convention on Reduction of Statelessness $1961 ; 102$ the Convention on the Rights of Persons with Disabilities (CRPD); and the Protocol to the African Charter on Human and Peoples' Rights on the Rights of Older Persons in Africa. ${ }^{103}$

During this period the government of Lesotho ratified more instruments than it had done in the past. This era also saw a change in the pattern of submission of state party reports to international treaty bodies. ${ }^{104}$ During this period Lesotho seems to have appreciated that state reporting is an obligation which has to be fulfilled, thus practically complying with the reporting obligation which previous regimes had not done. This paradigm shift towards international law was also illustrated in the enactment of laws, ${ }^{105}$ and in the application

91 Lesotho ratified this Convention on 27 January 1998.

92 Lesotho ratified the Protocol on 6 September 2000.

93 Lesotho ratified the Convention on 14 June 2001.

94 Lesotho ratified the Convention on 14 June 2001.

95 Lesotho ratified the Convention on 1 November 2001.

96 Lesotho ratified the Convention on 24 September 2003.

97 Lesotho ratified the Protocol on 24 September 2003.

98 Lesotho ratified the Protocol on 24 September 2003.

99 Lesotho ratified the Protocol on 28 October 2003.

100 Lesotho ratified the Convention on 24 September 2004.

101 Lesotho ratified on the Protocol on 24 September 2004.

102 Lesotho ratified the Convention on 24 September 2004.

103 Lesotho deposited its instrument of ratification in December 2018. Interview with Ms Nthabiseng Lelisa, legal officer, Ministry of Foreign Affairs on 26 February 2019.

104 African Commission on Human and Peoples' Rights Initial Report 2001 and also Combined Second to Eighth Periodic Report 2019; Human Rights Committee The Initial Report of Lesotho 16 October 1998, UN Doc CCPR/C/81/Add.14; CERD Committee The Initial Report of Lesotho 8 September 1998, UN Doc CERD/C/337/ Add.1; Committee on the Rights of the Child The Initial Report of Lesotho 20 July 1998 UN Doc CRC/C/11/Add.20; CEDAW Committee Combined Initial to Periodic Reports of Lesotho 26 August 2010 UN Doc CEDAW/C/LSO/1-4; Committee on Migrant Workers Initial Report of Lesotho 13 April 2016, UN Doc CMW/C/LSO/1.

105 Eg, the Sexual Offences Act 2003 and Legal Capacity of Married Persons Act 2006, which were aimed at gender mainstreaming in compliance with nondiscrimination as contained in art 1 of ICCPR, ICESCR and CEDAW, art 2 of the African Charter and art 2 of the African Women's Protocol. 
of international human rights treaties in the courts of Lesotho, as discussed in detail in the next part. After 1993 the courts started applying international human rights instruments and making pronouncements, albeit inconsistent, which leaned more towards the protection of human rights in accordance with Lesotho's human rights obligations.

\section{Application of international law in the courts of Lesotho}

\subsection{Courts' application of customary international law}

For purposes of this article 'application' refers to the use of customary international law by the courts, either as interpretative guide or as a course of judicial action on its own in the absence of corresponding domestic law. Customary international law, unlike international treaty law (discussed in the next part), seldom is applied or even referred to in the courts of Lesotho. One of the few cases in which a principle of customary international law was implied is the case of Lekhoaba. ${ }^{106}$ In this case the High Court found comfort in a rule of customary international law against statelessness and held that despite the prohibition of dual citizenship by the Constitution of Lesotho, section 42 of the Constitution bars Parliament from enacting laws the effect of which would render any person stateless. It emphasised that this is 'an immutable principle of the law of nations'. ${ }^{107}$ The Court took cognisance of the principle of customary international law, which is emulated in section 42 of the Constitution. What remains uncertain is whether the Court would adopt a similar approach if the Constitution was silent or had a provision which conflicted with this principle of customary international law.

\subsection{Courts' application of international treaty law}

The earliest case after independence in which the question of the application of international treaties in the courts of Lesotho was discussed is the case of Molefi. ${ }^{108}$ The appellant sought to be declared a refugee in terms of the UN Refugee Convention. The United Kingdom had ratified the Convention and extended its application to Lesotho during its protectorate days. One of the issues was whether the applicant could be declared a refugee under Lesotho law based on the definition of refugee contained in the UN Refugee Convention. The Court of Appeal (Privy Council) was confronted with the interpretation of section 38 of the Aliens Control Act 1966 in contrast to the UN Refugee Convention. It held that the letter written by the Prime Minister of Lesotho to the UN Secretary-General was a positive

106 Lekhoaba $v$ Director of Immigration \& Another Const/C/3/2007 [2007] LSHC 6.

107 Lekhoaba (n 106) para 64 (my emphasis).

108 Molefi (n 69). 
manifestation of the extent to which Lesotho intended to be bound by international instruments, including the Convention Relating to the Status of Refugees. ${ }^{109}$ It further held that on this ground the Appellant was a refugee as defined by the UN Refugee Convention. 110 However, the petitioner's circumstances did not fall within those contemplated in article 38 and, therefore, he could not be declared a refugee in terms of the Aliens Control Act. The Court held that the Refugee Convention was binding on Lesotho only because it had been transformed into the laws of Lesotho by virtue of section 38 of the Aliens Control Act.

The case of Mohollo Tšoenyane illustrates the theory of dualism in practice in that the High Court specifically held that whether bilateral or multilateral, in order for international agreements to be relied upon in domestic courts 'they require adoption by domestic legislatures'.111 In another case, Basotho National Party \& Another $v$ Government of Lesotho and Others, 112 in which the applicant sought an order directing the government of Lesotho to 'adopt such legislative and other measures necessary to give effect to the rights recognised in international conventions', 113 the Court dismissed the application and stated that 'these Conventions cannot form part of our law until and unless they are incorporated into municipal law by legislative enactment'. ${ }^{114}$ The Court emphasised: ${ }^{115}$

The Court cannot usurp the functions assigned the executive and the legislature under the Constitution and it cannot even indirectly require the executive to indirectly introduce a particular legislation or the legislature to pass it or assume itself a supervisory function over the law-making activities of the executive and the legislature.

The refusal by the courts to apply international human rights instruments in the cases of Tšoeunyane and $B N P$ is evidence of a strict dualist approach to international law during Lesotho's early years of democracy. A similar approach is seen later, in 2013, in the case of Masupha. ${ }^{16}$ This case was lodged by the daughter of a late principal chief. She sought an order declaring section 10 of the Chieftainship Act 1968, on the basis of which succession to office of chief is limited to first-born male children, discriminatory and, therefore, unconstitutional. Among instruments cited to advance the arguments that Lesotho had an obligation not to discriminate on the basis of sex were ICCPR, CEDAW, the African Charter and the Protocol to the

109 As above (unnumbered paras).

110 As above (unnumbered paras).

111 Director of Public Prosecutions v Mohollo Tšoenyane \& Others CR/299/99 (High Court of Lesotho) unreported 25 February 2000 para 6.

$112 B N P \vee$ Government of Lesotho \& Others (n 24).

$113 B N P$ (n 24) para 2.

114 BNP 22.

115 BNP 23.

116 Senate Gabasheane Masupha v Senior Resident Magistrate for the District of Berea \& Others C of A (CIV) 29/2013 [2014] LSCA. 
African Charter on Human and Peoples' Rights on the Rights of Women in Africa (African Women's Protocol). However, the Court held: ${ }^{117}$

These instruments, it is clear, are aids to interpretation not the source of rights enforceable by Lesotho citizens. In the present matter, there's no aspect of the process of interpreting section 10 of the [Chieftainship] Act, which leaves its meaning exposed to any uncertainty, to the resolution of which the instruments in question could contribute further than the considerations, which have already been taken into account.

The Court did not rule out international instruments as completely irrelevant to the inquiry, but stated that they could be helpful only as interpretative guides if there was uncertainty in the interpretation of section 10 of the Chieftainship Act. By holding that international human rights instruments to which Lesotho is a party are 'not the sources of rights enforceable by Lesotho citizens', the Court exonerated the state from its international human rights obligations in the absence of an Act of Parliament. That is, despite its being blatantly discriminatory, the Chieftainship Act was upheld and not tested against international human rights standards against discrimination. In the context of this article it may be concluded that the Court erred as it did not take into account the fact that non-discrimination on the basis of sex is an established principle of customary international law which binds all states even in the absence of ratification of an international human rights treaty that outlaws discrimination. 118

Prior to the BNP and Masupha cases, the High Court of Lesotho, in the cases of Sello $v$ Commissioner of Police \& Others ${ }^{119}$ and Law Society of Lesotho $v$ Right Honourable Prime Minister ${ }^{120}$ had approached human rights cases in a more pragmatic manner. The case of Sello was an application of habeas corpus for production in court of a woman who had been detained under the Internal Security Act (General) 1984 for more than 20 days without access to any visitors. The Court held that while the Internal Security Act authorised such an arrest, the Act should be interpreted bearing in mind the rights of individuals, and further held that it 'may it also be remembered that this Kingdom is a signatory to the Declaration of Human Rights Charter' (sic). ${ }^{121}$ The Court implied that the rights of the individual as contained in international human rights instruments should be given preference over a domestic law where such law authorises the violation of such rights.

117 Senate Gabasheane Masupha (n 116) 28.

118 JP Humphrey 'The implementation of international human rights law' (19781979) 24 New York Law School Law Review 31; see also ICJ Case Concerning the Barcelona Traction, Light and Power Company, Limited (Belgium v Spain) Judgment of 5 February 1970, ICJ Reports, 1970 para 34.

119 Sello $v$ Commissioner of Police \& Others CIV/APN/10/1980 (High Court of Lesotho) unreported 22 February 1980.

120 Law Society of Lesotho $v$ Right Honourable Prime Minister C of A (CIV) 5 /1985 (Lesotho Court of Appeal) unreported 3 September 1985.

121 Sello (n 119) 17. 
The case of Law Society of Lesotho $v$ Right Honourable Prime Minister involved the independence of the judiciary in which a former officer of the Attorney-General's office and Director of Public Prosecutions had been appointed as an acting judge. ${ }^{122}$ The Court was called upon to interpret the Human Rights Act of 1983, which has since been repealed by the 1993 Constitution. In its interpretation of the Human Rights Act, the Court of Appeal relied on the Universal Declaration of Human Rights (Universal Declaration) and the extent to which it had influenced the Human Rights Act. The Court concluded that the interpretation of the Human Rights Act should be done in accordance with international human rights law. ${ }^{123}$ It reiterated the role that international law played in shaping the national legal framework, including the Human Rights Act. The reminder that the Human Rights Act was anchored in international human rights law thus reflects the Court's willingness to align its interpretation with what obtains in the realm of international law.

In the case of Sole $e^{124}$ the Court had to determine whether the right to legal representation as contained in section 12 of the 1993 Constitution could be extended to include an accused person's right to be represented in a criminal trial by a former Director of Public Prosecutions who had been involved on behalf of the state in the investigations leading to his charge. The Court referred to a number of cases from different jurisdictions in the Commonwealth, namely, South Africa, as well as to the European Court of Human Rights, and to a number of international treaties such as ICCPR, the African Charter, the European Convention and the Inter-American Convention. The Court found the dicta of the European Court 'instructive'.125 It considered all arguments and the relevant instruments, and ultimately drew inspiration from a judgment by the European Court. That is, although the Court did not hold that Lesotho has obligations under the European Convention, it used jurisprudence of the European Court, which forms part of international law, to justify its own decision that the right to legal representation is not an absolute right. ${ }^{126}$

In the case of Lesotho Revenue Authority $v$ Master of the High Court \& Others, ${ }^{127}$ the Court held that in interpreting the national laws, as well as the Constitution, a fair balance between the public interest and the rights of the individual has to be established. ${ }^{128}$ The Court borrowed the principle of fair balance from article 1 of the European Convention, which had been used by Ackermann JA in the South African case of First National Bank and Another $v$ Commissioner of South

122 Law Society of Lesotho (n 120) 2.

123 Law Society of Lesotho 19.

124 DPP $v$ Sole \& Another [2001] LSHC 63.

$125 D P P \vee$ Sole $(\mathrm{n} 124) 57$.

$126 D P P \vee$ Sole 58.

127 CIV/APN/67/2004, [2004] LSHC 55 (LRA).

$128 L R A(\mathrm{n} 127)$ para 90. 
African Revenue Services \& Others. ${ }^{129}$ Although the Court's use of the principle of fair balance was not a departure from dualism as it was used to justify the Court's own interpretation of the Constitution, this approach, however, is illustrative of the role that the rights of individuals play in the interpretation of national laws, regardless of the source of such rights.

In cases involving the rights of children, the courts have not flinched from considering CRC and African Children's Charter where the best interests of the child principle is employed. The courts' justification in such instances could be the fact that the Children's Protection and Welfare Act (CPWA) 2011 incorporates the said conventions in the following words: 130

The objects of this Act are to extend, promote and protect the rights of children as defined in the 1989 United Nations Convention on the Rights of the Child, the 1990 African Charter on the Rights and Welfare of the Child and other international instruments, protocols, standards and rules on the protection and welfare of children to which Lesotho is a signatory.

The case of Malefetsane Mohlomi was a review of a criminal trial of two accused persons aged 16 and 17 years who had been convicted, together with two adults, for a contravention of the Sexual Offences Act 2003. ${ }^{131}$ The Court held that because the 16 and 17 year-olds were children as defined in the CPWA, they ought not to have been tried together with the two adults. It held further that the joint trial was a violation of their rights and ordered a fresh trial which took into account the best interests of the child principle as expounded in CRC and the African Children's Charter. ${ }^{132}$

A similar approach regarding the applicability of the African Charter and CRC was adopted in the cases of Mapetla $v$ Leboela ${ }^{133}$ and $L v$ $M,{ }^{134}$ which dealt with the custody of minor children. In the former case the Court specifically held that the international law principle of best interests of the child was particularly relevant in the courts of Lesotho because of section 4 of the Children's Protection and Welfare Act 2011, which reiterates the said principle. In the latter case the Court of Appeal held that the High Court had erred by ignoring arguments based on CRC and the African Children's Charter as these

1292002 (4) SA 768, cited in LRA (n 127).

130 Sec 2 Children's Protection and Welfare Act 2011. Lesotho is a state party, rather than a 'signatory', to these treaties.

131 Rex v Malefetsane Mohlomi \& Others 14 March 2013 [2013] LSHC 27 paras 1-3.

132 Malefetsane Mohlomi (n 131) para 105. For a discussion of children's rights under CRC and the African Children's Charter, see A Skelton 'The development of a fledgling child rights jurisprudence in Eastern and Southern Africa based on international and regional instruments' (2009) 9 African Human Rights Law Journal 482.

133 Leboela $v$ Mapetla C of A (CIV) 44/2011 [2012] LSCA 2.

$134 L v M 21$ C of A (CIV) 29/2011 [2011] LSCA 29. 
international instruments were 'authoritative since Lesotho had ratified them in March 1992 and November 1992 respectively'. 135

In a similar manner, conventions of the International Labour Organisation (ILO) are applied with ease by both the Labour Court and the Labour Appeal Court because of section 2 of the Labour Code Order 1992, which provides:

In cases of ambiguity, provisions of the Code shall be interpreted in such a way as more closely conforms with the provisions of conventions adopted by the conference of the ILO and of recommendations adopted by it.

The above cases reflect the courts' move from relying exclusively on domestic laws when dealing with human rights to incorporating Lesotho's international human rights obligations in their interpretation. While this move does not contradict the theory of dualism, the cases mark a starting point from which the courts then took a further step and made pronouncements in which they regarded international instruments as sources of rights for the people of Lesotho. The cases in which this paradigm shift is illustrated include the case of Judicial Officers of Lesotho \& Another $v$ the Right Honourable Prime Minster \& Another ${ }^{136}$ in which magistrates sought an order declaring Rule 16 of the Judicial Commission Rules, as well as the government directive which assigned magistrate's courts to District Administrators, unlawful and contrary to the principle of separation of powers. The Court held that besides section 118 of the Constitution 'Lesotho is also a party to ICCPR, the African Charter and Universal Declaration of Human Rights, which all impose on state parties, the duty to guarantee independence of the courts'. ${ }^{137}$

Similarly, in Moosa \& Others $v$ Magistrate Ntlhakana \& Others ${ }^{138}$ the Court took cognisance of the fact that 'Lesotho has signed the African Union Convention on the African Charter on Human and Peoples' Rights (sic) regarding the rights of citizens'. ${ }^{139}$ Makhasane was a trial for damages arising out of unlawful arrest and detention, as well as verbal and physical abuse. ${ }^{140}$ In determining the amount of damages, the Court took into account the fact that the 'African Charter protects a number of civil and political rights, including the right to dignity',141 and held that such rights had been infringed by the police who unlawfully arrested and detained the complainant. ${ }^{142}$

$135 L v M(\mathrm{n} 134)$ para 5.

136 Judicial Officers of Lesotho (JOALE) \& Another v The Right Honourable Prime Minster \& Another Constitutional Case 3/2005 [2006] LSHC 150.

137 Judicial Officers of Lesotho (n 136) 17.

138 CIV/APN/167/2007 [2007] LSHC 83 (Moosa).

139 Moosa (n 138) para 40. Lesotho has ratified the African Charter on Human and Peoples' Rights.

140 Makhasane $v$ Commissioner of Police \& Others CIV/T/401/2006 [2011] LSHC 20.

141 Makhasane (n 140) (unnumbered paragraphs and pages).

142 As above. 
The Makhasane case illustrates the shift even more clearly in that the Constitution of Lesotho does not provide specifically for the right to dignity. Therefore, in finding that the plaintiffs' right to dignity had been violated the Court relied on article 5 of the African Charter. Similarly, when making reference to the right to freedom from torture, the Court of Appeal of Lesotho in the case of Makotoko Lerotholi \& Others $v$ Director of Public Prosecutions held: ${ }^{143}$

Even the police are mandated by the law as well the provisions of international laws and conventions regarding the rights of suspects to which this country is signatory, to treat suspects humanely and in accordance with the law ... the suspects are equally entitled to a fair, human and just treatment in keeping with domestic and international law.

The most celebrated cases in which the courts' pronouncements on international law were very clear are the cases of Molefi Tšepe $e^{144}$ and Fuma. ${ }^{145}$ These decisions are celebrated not only because of their contribution to the enforcement of the rights of women and people with disabilities, respectively, but also because of the courts' bold and extensive interpretation of Lesotho's international obligations as contained in the international human rights instruments. In the Tšepe case the applicant, a male local government elections candidate, sought an order declaring the reservation of a one-third quota of all local government seats for women under the Local Government Elections Act 1998 (as amended by an Amendment Act of 2005) to be discriminatory and unconstitutional. Relying on articles 3 and 26 of ICCPR, ${ }^{146}$ HRC General Comment $18,{ }^{147}$ articles 3 and 4 of CEDAW, ${ }^{148}$ articles 18(3) and (4) of the African Charter, as well as the SADC Declaration on Gender Equality, ${ }^{149}$ the Court held that the Amendment Act was not discriminatory but constituted an affirmative action measure which Lesotho had an international human rights obligation to observe. The Court stated: ${ }^{150}$

If regard be had to Lesotho's international law obligations, these, if anything, reinforce the interpretation of section $18(4)(\mathrm{e})$ of the Constitution and require equality, which is substantive and not merely formal and restitutionary in its reach.

The Fuma case was lodged by a member of the Lesotho Defence Force (LDF) who had been forced to retire in terms of section 24 of the LDF Act on the grounds that he was legally blind because of an HIV infection, among others. ${ }^{151}$ He challenged the decision of the LDF to retire him as discriminatory as there was an option of giving him

$143 \mathrm{CRI} / \mathrm{A} / 23 / 2007$ (Lesotho Court of Appeal) 7 July 2007 (unreported).

144 Molefi Tšepe v IEC CIV/APN/135/2005 [2005] LSHC 96.

145 Fuma $v$ Commander LDF Cons Case 08/2011 [2013] LSHC 68.

146 Tšepe (n 144) para 17.

147 Tšepe para 18.

148 Tšepe para 17.

149 Tšepe para 21.

150 Tšepe para 22.

151 Fuma (n 145) summary. 
lighter duties which befitted his condition - as had been done with other visually-impaired army officers. He argued that his HIV status was the only factor on which the decision to retire him was based. In deciding in his favour the Court held: ${ }^{152}$

The unreservedly ratified United Nations Convention on the Rights of Persons with Disabilities stands not only as an aspirational instrument in the matter, but that by default, it technically assumes the effect of municipal law in the country.

Having considered the relevant provisions of CRPD, the Court went further to hold that '[t]he [CRPD] stands not only as an inspirational instrument in the matter but that by default it technically assumes the effect of the municipal law in the country'. ${ }^{153}$ The Court found a violation of sections 18 and 19 of the Constitution of Lesotho, which it held had to be interpreted so as not to contradict with Lesotho's obligations under CRPD.

As illustrated above, in the majority of cases the courts were persuaded by the international instruments and were satisfied by the fact that Lesotho had ratified such instruments and, therefore, was bound to act as mandated thereby. The courts raised no issues about whether the relevant treaties had been domesticated or not. This stance notwithstanding, one other visible trend in Lesotho courts is the limited application of international human rights instruments adopted under the auspices of the Organisation of African Unity (OAU) and the African Union (AU). The majority of cases in which international treaties were referred to were continental treaties, and in very few cases treaties that had been adopted at the regional level were referred to or used as interpretative guides.

\section{Conclusion}

While the relationship between international law and national law traditionally has been analysed on the basis of a monist-dualist dichotomy, the discussion of these theories and their impact on human rights protection in Lesotho as well as their contrast with practice challenge their expediency in human rights protection. As Oppong correctly observes, the debates around these theories focus more on the source or pedigree of the norm, that is, whether it emanates from a national or international source, and ignore the content or the substance of the norm in question. ${ }^{154}$ This would thus encourage states to violate human rights with impunity knowing that in the absence of the domestication of international human rights instruments victims have no recourse to the national courts of law.

152 Fuma para 22.

153 Fuma para 56.

154 Oppong (n 4) 2. 
The cases discussed in the article have illustrated that the courts of Lesotho have gone beyond the monist-dualist dichotomisation in favour of human rights protection. The courts also emphasised the need for compliance with international human rights instruments to which Lesotho is a party. This mutual relationship between the two legal systems, therefore, discards observations of some authors that argue that international law and domestic law 'are definitely an odd couple'.155 For instance, in the Makhasane case the finding of a violation of the right to dignity was based on the African Charter as opposed to the Constitution of Lesotho.

Taking into account the fact that Lesotho currently is undergoing comprehensive national reform, it is important that this shift also be included in the Constitution as one of the ways of enhancing human rights protection and ensuring accountability. This change already has taken place in other Anglophone African countries that during colonisation had inherited Roman-Dutch law. These countries have since adopted new constitutions which clarify the position of international law in their national legal systems. For instance, the Constitution of Zimbabwe contains a provision which mandates courts to take international law into account. ${ }^{156}$ Consequently, the Zimbabwean Constitutional Court in the case of Mudzuru held that by ratifying CRC and the African Children's Charter, 'Zimbabwe expressed its commitment to take all appropriate measures, including legislative, to protect and enforce the rights of the child as enshrined in the relevant conventions to ensure that they are enjoyed in practice'. ${ }^{157}$ Similarly, section $39(1)(b)$ of the South African Constitution mandates courts and tribunals to consider international law when interpreting the Bill of Rights. The clear stipulations on the extent to which international law must be used by courts assist the courts to uniformly approach international human rights treaties.

155 Torrijo (n 13) 485.

156 Secs $32 \& 46$ Constitution of Zimbabwe 2013.

157 Mudzuru \& Another $v$ The Minister of Justice, Legal and Parliamentary Affairs \& 2 Others CCZ 12/2015 (Constitutional Court of Zimbabwe) 14 January 2015 \& 20 January 201627. 